\title{
Tax Awareness and Compliance: An Empirical Study on Small and Medium-Sized Enterprises (SMES)
}

\author{
Hadri Kusuma ${ }^{1 *}$, Famita Azzakhusna ${ }^{2}$ \\ ${ }^{1}$ Universitas Islam Indonesia, Indonesia \\ ${ }^{2}$ Gadjah Mada University
}

*Corresponding Author: Hadri Kusuma, Universitas Islam Indonesia, Indonesia

\begin{abstract}
The issue of tax compliance has been explored over many years from different perspectives. These studies have investigated determinants of tax compliance and assumed that those are direct relationships. This study aims to analyze the determinants of tax awareness. The study adds a new variable namely appreciation strategy on the determinants. It also investigates the relationship between tax awareness and tax compliance. Based on the survey from 150 small and medium-sized enterprises, empirical findings confirm the prevalence of the behavior control and subjective norm dimensions as determinants of tax awareness. Interestingly, the result also endorses the validity of the appreciation strategy in tax awareness behavior. This study contributes to the current literature by adding a new variable of the appreciation strategy in the tax compliance model. The research model also suggests the indirect influence of the current determinants of tax compliance, but tax awareness can be an intervening variable of the prevalent determinants.
\end{abstract}

Keywords: Compliance, Awareness, Appreciation strategy, Subjective Norm, and Behavior Control.

\section{INTRODUCTION}

Tax is the largest source of state revenue with no time limit (Syahputri, 2015). In addition, tax also has a significant role and is increasingly reliable for development and government expenditure (Syahputri, 2015). Based on the Decree of the Minister of Finance No. 544 / KMK.04 / 2000, tax compliance is defined as follow:

- Timely submission of SPT (Tax Return) for all types of taxes in the last 2 years; having no tax arrears for all types of taxes unless having obtained permission to pay in installments or delay payment of taxes,

- Never been sentenced for committing a criminal offense in taxation in the past 10 years,

- Organizing bookkeeping in the last 2 years; and if a taxpayer has ever been inspected, the last correction for each type of indebted tax is maximum 5\%; a taxpayer whose financial statements for the last 2 years have been audited by public accountants with unqualified or qualified opinion as long as it does not affect fiscal income.

Tax compliance can be divided into two types, namely formal compliance and material compliance (Nurmantu in Hariyanto, 2012). Formal compliance is related to the deadline for collecting Annual Tax Returns, which is March 31. An example of formal compliance is a taxpayer who collects the Annual Tax Return before March 31. However, a taxpayer who fulfills formal compliance criteria does not always fulfill the criteria of material compliance. Material compliance is a condition in which a taxpayer fulfills all material provisions in the form of truthful content in accordance with tax laws. A taxpayer who complies with material compliance fulfills formal compliance.

Data related to tax compliance in 2014 and 2015 are shown in table 1. The level of tax compliance ratio of individuals and corporates is still relatively low. Even though there is an increase in each year, tax revenue especially from corporate taxpayers is still low compared to others. The level of tax compliance ratio of corporate taxpayers is still below the individual taxpayers.

Table1: Level of Tax Compliance

\begin{tabular}{|l|l|l|}
\hline & \multicolumn{1}{|c|}{$\mathbf{2 0 1 4}$} & \multicolumn{1}{c|}{$\mathbf{2 0 1 5}$} \\
\hline Individual Taxpayer & $9,44 \%$ & $9,4 \%$ \\
\hline
\end{tabular}




\begin{tabular}{|l|l|l|}
\hline Corporate Taxpayer & $91,91 \%$ & $91,95 \%$ \\
\hline Compliance Ratio & $60,42 \%$ & $58,87 \%$ \\
\hline
\end{tabular}

Source: http://www.pajak.go.id. April 5 2017; 09:45 pm

Previous studies on factors encouraging taxpayers to be obedient examined behavior (Winarsih, 2015) and Syahputri, 2015), tax knowledge (Syahputri, 2015 and Engida and Baisa, 2014), services (Komala et al., 2014, and Suntono and Kartika, 2015), sanctions (Lesnik et al., 2014 and Engida and Baisa, 2014), trust in tax apparatus (Bornman and Stack, 2015, Hauptman et al., 2015 and Sapiei et al. (2014 ), subjective norms (Syahputri, 2015 and Hauptman et al., 2015), and behavior control (Winarsih, 2015). However, the results of these studies are mixed. This may be caused by the difference in the research models and the assumption that all mentioned independent variables directly influenced tax compliance. Hauptman et al. (2015) suggested the inclusion of taxpayer appreciation strategy in the research model.

This study aimed to analyze the influence of behavior control, subjective norm and appreciation strategy on tax awareness and the influence of tax awareness on tax compliance. This study focused on variables that had not been consistent and suggested by the previous studies. Previous studies examined direct determinants of tax compliance, while this study assumed that the determinants did not directly affect tax compliance but through tax awareness as an intervening variable (Hauptman et al., 2015). The addition of appreciation strategy and the improvement of the research model were based on the suggestion of Winarsih (2015), Khairah (2015) and Indriyani and Sukartha (2014).

\section{THEORETICAL GROUND}

\subsection{Theory of Planned Behavior}

Theory of Planned Behavior (TPB) explains that the main factor of individual behavior is that the influence of individual intention (behavior intention) towards a particular behavior (Winarsih, 2015). According to Ajzen (1991) in Winarsih (2015), people can have various kinds of beliefs toward a behavior, but when faced with a particular event, only a few of these beliefs influence them to behave in a certain way.

Regarding this study, TPB is relevant to explain the taxpayer's behavior to be aware and obedient to tax. Taxpayers will obey the tax if they have strong intentions and beliefs. In addition, taxpayers also consider the consequences of their behavior, before behaving in a certain way.

The TPB model explains that behavior is influenced by the intention. The intention is influenced by several factors, namely Attitude, Subjective Norm, and Perceived Behavior Control. This model is relevant to the current research model as shown in figure 1.

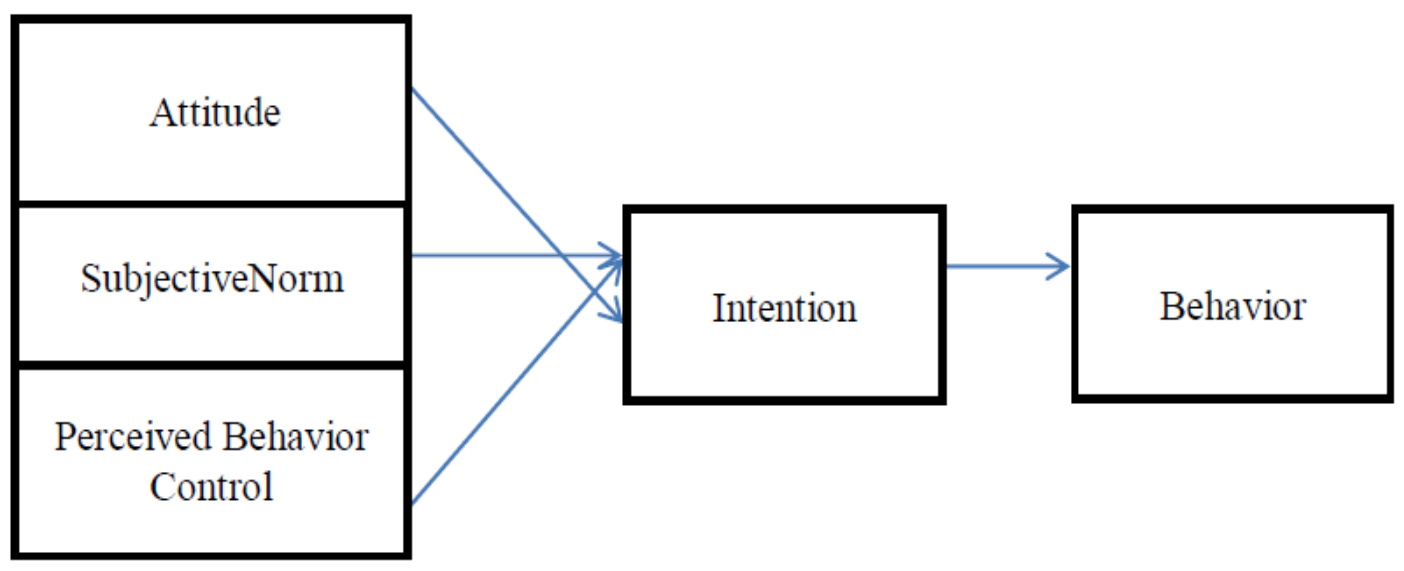

Figure1: Theory of Planned Behavior Model

Figure 1 shows that behavior control variable in this study represents Perceived Behavior Control in the TPB model because both variables indicate that behavior occurs because of the intention and belief of a conscious individual (small and medium enterprises). Subjective Norm variable in this study is similar to Subjective Norm in the TPB model in the sense that individual behavior caused by intention influenced by social pressure from colleagues, clients, or competitors. The appreciation strategy in this study represents Perceived Behavior Control in the TPB model since the emergence of 
behavior is caused by an intention from an understanding of the benefit of tax awareness. The tax awareness variable represents intention in the TPB model because awareness is a reflection of someone's intention regarding tax compliance. Tax Compliance variable represents Behavior (Behavior) because compliance is a form of behavior regarding tax obedience.

\subsection{Social Learning Theory}

Social learning theory explains that someone can learn through direct observation and experience (Bandura, 1997 in Jatmiko, 2006). This theory is an extension of the operant conditioning theory (Skinner, 1971 in Jatmiko, 2006), which is a theory that presupposes behavior as a function of consequences. According to Bandura (1977, in Jatmiko, 2006), the process in social learning includes: first, the process of attention, in which an individual can learn from others if he/she pays attention to them; second, the retention process, which is the process of remembering an action of a model after the model is no longer available; third, the process of motor reproduction, which is the process of turning observation into actions; and fourth, the process of motivation, in which someone is given positive motivation to behave appropriately according to the model. Regarding this study, the Social Learning Theory is relevant to explain the behavior of a taxpayer related to tax obedience. A taxpayer will be obedient if he/she has directly observed and experienced it, especially after knowing that tax has a real contribution to the development of a region (Jatmiko, 2006).

According to KamusBesarBahasa Indonesia, compliance means submitting to or obeying a rule. Compliance is the motivation of a person, a group or an organization to act or not act according to established rules. A person's respectful behavior is the interaction between the behavior of individual, group, and organization (MGibson 1991 in Jatmiko, 2006). According to E. Eliyani (1989) in Jatmiko (2006), tax compliance is defined as reporting required information, correctly filling the amount of tax owed, and paying taxes on time without any coercion. More accurate calculation and submission of the tax return are expected to result in a higher level of tax compliance.

\subsection{Hypothesis Development}

Referring to the theories above, the research model is presented in Figure 2. The model is the development of the TPB model with the incorporation of appreciation strategy instead of attitude.

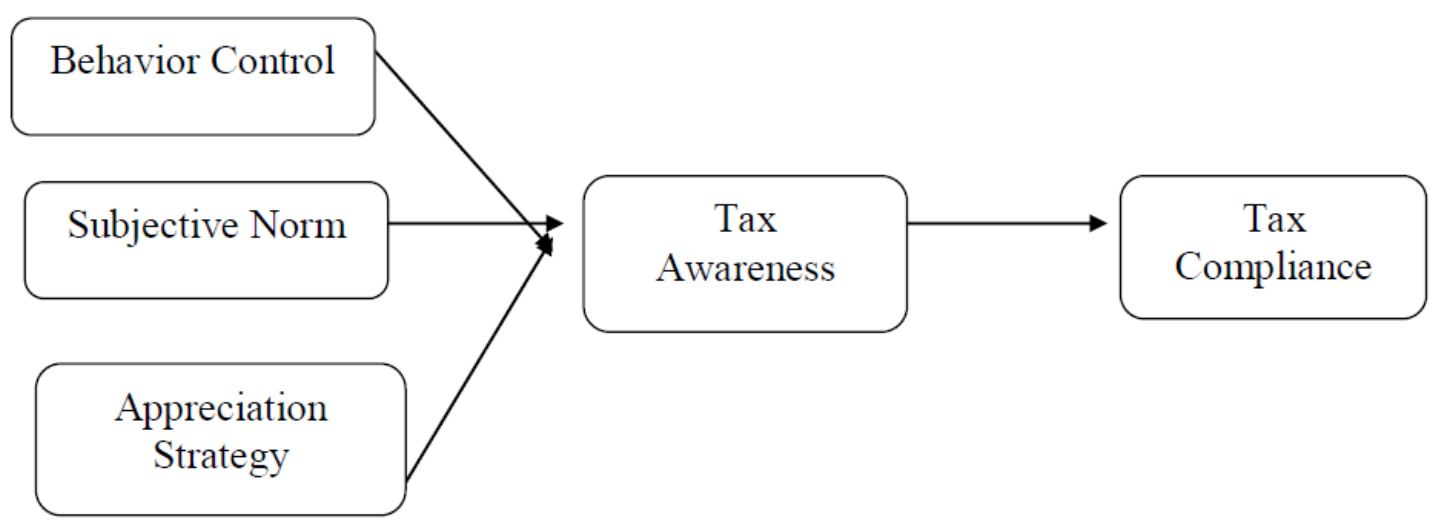

Figure3: Research Framework

\subsubsection{Appreciation Strategy and Tax Awareness}

Appreciation is given for motivating someone to be more enthusiastic in doing an activity (Anwar and Dunija, 2016). According to Anwar and Dunija (2016), appreciation can be in the form of situation or verbal list that will produce satisfaction or increase the possibility of learning actions. Besides, Dianingtyas (2014) stated that appreciation is given for a particular achievement both from an individual or an institution in the form of material or speech.

Social learning theory explains that someone can learn through direct observation and experience (Bandura, 1997 in Jatmiko, 2006). The relevance of the Social learning theory to appreciation strategy is that a taxpayer will try to be more aware of and comply with tax rules if he/she observes that there will be a form of appreciation for his/her obedience. The inclusion of appreciation strategy as a variable was based on Bornman and Stack (2015). Thus, the hypothesis was formulated as follow:

H1: Appreciation strategy has a positive influence on tax awareness. 


\subsubsection{Behavior Control and Tax Awareness}

Tax awareness is a state of knowing or understanding tax matters. It is one of the factors that influence the level of tax compliance (Astana and Merkusiwati, 2017). Tax awareness can be seen from taxpayer sincerity, understanding, and desire to fulfilling tax obligations (Astana and Merkusiwati, 2017). Furthermore, according to Muliari in Astana and Merkusiwati (2017), tax awareness is a good intention of someone to fulfill the obligation to pay tax voluntarily. In Indonesia, taxpayers are responsible for counting, calculating, paying, and reporting indebted tax, and it requires their awareness. In fact, tax awareness still becomes a problem. According to Lerche (1980) in Jatmiko (2006), tax awareness is needed to improve tax compliance; the higher the tax awareness, the higher the level of tax compliance.

Behavior control is the level of control a taxpayer has certain behaviors, such as reporting lower income than the actual one, fixing expenses and income in tax return, and other non-compliance behaviors (Bobek and Hatfield, 2003 in Winarsih, 2015). Ajzen (1991) in Winarsih (2015) reported that perceived behavior control influenced intention based on the assumption that individual behavior control had a motivational implication for that person. Ajzen (2005) in Syahputri (2015) found that behavior control was perceived to directly or indirectly influence the intention to behave. According to Winarsih (2015), behavior control is a specific control that taxpayers believe will prevent them from displaying awareness to be obedient.

The theory of Planned Behavior explains that the main factor of a certain behavior is an individual intention (behavior intention) to that behavior (Winarsih, 2015). The intention may also affect the level of tax awareness. Winarsih (2015) suggested that behavior control affected tax compliance. Meanwhile, Syahputri (2015) did not support the finding. From the consideration above, the following hypothesis was formulated:

\section{$\mathrm{H} 2$ : Behavior control has a positive influence on tax awareness.}

\subsubsection{Subjective Norm and Tax awareness}

Subjective Norm is individual perception of social influence in shaping a particular behavior (Ajzen, 1991 in Winarsih, 2015). Subjective norm is a function of perceived expectations that surrounding people, for example, siblings and colleagues, approve a certain behavior and motivate an individual to obey them (Winarsih, 2015). In addition, subjective norm is also individual perception of a relationship with influential people that have an impact on the behavior that will be carried out. It can be said that subjective norm is the extent to which an individual is motivated to follow others' views on a certain behavior (Syahputri, 2015).

The Theory of Planned Behavior explains the existence of a belief about the influence of surrounding people, such as family, colleagues, and friends, who can motivate a taxpayer to be on not to be aware of and compliant to tax. Syahputri (2015) and Hauptman et al. (2015) suggested that subjective norm influenced tax compliance while Winarsih(2015) reported otherwise. Thus the following hypothesis was formulated:

\section{H3: Subjective Norm has a positive influence on tax awareness.}

\subsubsection{Tax Awareness and Tax Compliance}

Compliance is the motivation of a person, group or organization to act or not to act according to established rules. Individual obedient behavior is the interaction between the behavior of individuals, groups and organizations (MGibson 1991 in Jatmiko, 2006). According to E. Eliyani (1989) in Jatmiko (2006),tax compliance is defined as submitting required information, correctly filling the amount of tax owed, and paying taxes on time without coercion. The higher the accuracy and timeliness of tax return, the higher the level of tax compliance.

Social learning theory states that an individual can learn through direct observation and experience (Bandura, 1997 in Jatmiko, 2006). Taxpayers will be sincerely aware of taxes if they have understood the tax function based on their direct observation. The higher the level of tax awareness, the better the understanding and implementation of tax compliance (Astana and Merkusiwati, 2017). Astana and Merkusiwati (2017) reported that tax awareness influenced tax compliance. Thus, the hypothesis was formulated as follow:

\section{H4: Tax awareness has a positive influence on tax compliance.}




\section{RESEARCH METHOD}

The population of this study was all small and medium-sized enterprises (SMEs) in the Special Region of Yogyakarta. The samples were selected using purposive sampling with the following criteria:

- SMEs operating for more than 5 years.

- SMEs with revenue exceeding Rp. 8,000,000/month.

All data were primary data obtained from distributing questionnaires to SMEs owners as respondents. Tables 2 and 3 show the number of questionnaires and the distribution of respondents.

Table2: Data Collection Results

\begin{tabular}{|l|l|l|}
\hline \multicolumn{1}{|c|}{ Information } & \multicolumn{1}{c|}{ Total } & \multicolumn{1}{c|}{ Percentage } \\
\hline Distributed questionnaire & 140 & $100 \%$ \\
\hline Returned questionnaire & 130 & $93 \%$ \\
\hline Unreturned questionnaire & 10 & $7 \%$ \\
\hline Processed questionnaire & 105 & $75 \%$ \\
\hline Unprocessed questionnaire & 25 & $18 \%$ \\
\hline
\end{tabular}

Table3: Questionnaire Distribution

\begin{tabular}{|c|c|c|}
\hline Regency/City & Total & Percentage \\
\hline Yogyakarta & 45 & $43 \%$ \\
\hline Sleman & 20 & $39 \%$ \\
\hline Bantul & 35 & $2 \%$ \\
\hline Kulonprogo & 2 & $3 \%$ \\
\hline GunungKidul & 3 & $\mathbf{1 0 0 \%}$ \\
\hline Total & $\mathbf{1 0 5}$ & \\
\hline
\end{tabular}

Table4: Research Variables and References

\begin{tabular}{|l|l|l|l|}
\hline No & \multicolumn{1}{|c|}{ Variable } & \multicolumn{1}{|c|}{ Total Question } & \multicolumn{1}{c|}{ Reference } \\
\hline 1 & Awareness & 6 & Astana dan Merkusiwati (2017) \\
\hline 2 & Appreciation strategy & 4 & Bornman dan Stack (2015) \\
\hline 3 & Subjective Norm & 3 & Syahputri (2015) \\
\hline 4 & Behavior Control & 5 & Winarsih (2015). \\
\hline 5 & Tax compliance & 5 & SuntonodanKartika, 2015) \\
\hline
\end{tabular}

The research variables in this study were measured using an interval scale of 1 (strongly disagree) to 4 (strongly agree). The questions in the questionnaire were taken from previous studies that have been tested with several developments by the researchers. Table 4 presents and summarizes the number of question items in the questionnaire for each variable along with the references used.

The data were analyzed using simultaneous equation with path analysis estimation. Path Analysis is the development of a multiple linear regression model for analyzing the suitability of correlations between two or more research models that are built based on theory. Mathematical equations 1 and 2 were used to test the hypotheses.

$$
\begin{aligned}
& X_{4}=\beta_{1} X_{1}+\beta_{2} X_{2}+\beta_{3} X_{3}+\varepsilon \\
& Y=\beta_{4} X_{4}+\varepsilon
\end{aligned}
$$

Whereas:

$\mathrm{Y}$

$\mathrm{X}_{1}$

$\mathrm{X}_{2}$

$\mathrm{X}_{3}$

$\mathrm{X}_{4}$

$\mathrm{B}_{1-4}$

$\varepsilon$
: Tax Compliance

: Behavior Control

: Subjective Norm

: Appreciation strategy

: Tax awareness

: Path Coefficient Value

: Error 
The data quality was examined by considering the result of validity and reliability tests. A validity test is conducted to determine whether or not a questionnaire is valid; it is considered valid when the questions can reveal something intended to be measured (Ghozali, 2009 in Winarsih, 2015). This study included convergence validity and discriminant validity. Convergence validity means high correlation of construct measurement (Ghozali and Latan, 2014). According to Ghozali and Latan (2014), convergence validity with reflective indicators is tested by considering the outer loading value above 0.7. The result of the correlation output between the indicator and the construct using Smart PLS 2.0 M3 showed that the outer loading value was above0.70, and thus the question items met convergent validity. Determinant validity means that different construct measurements are not highly correlated (Ghozali and Latan (2014). According to Ghozali and Latan (2014), determinant validity with reflective indicators is tested by considering the cross-loading value above 0.7 . The discriminant validity test result showed that the cross-loading value was above 0.70 , and the question items met the criteria of discriminant validity.

The reliability test is used to determine if the variables are free from errors so that they have consistent results even if tested for many times (Winarsih, 2015). Reliability is also meant to find out the consistency of a measuring instrument. According to Ghozali and Latan (2014), reliability is measured by considering composite reliability values above 0.7 . The test result indicated that all constructs in this study were reliable.

\section{RESULTS AND DISCUSSIONS}

\subsection{Respondent Characteristics}

All respondents were categorized grouped according to age, gender, age of the enterprise, and revenue per month. Those characteristics are explained below.

\subsubsection{Respondent Characteristic Based on Age}

Table 5 shows that there were 14 respondents (13\%) aged 20-30 years old, 33(31\%) aged 31-40 years old, $31(30 \%)$ aged 41-50 years old, $25(24 \%)$ aged 51-60 years old, and $2(2 \%)$ aged over 60 years old. Therefore, the majority of respondents were aged $31-40$ years old.

Table5: The Percentage of Respondents'Age

\begin{tabular}{|l|l|l|}
\hline \multicolumn{1}{|c|}{ AGE } & \multicolumn{1}{|c|}{ TOTAL } & \multicolumn{1}{c|}{ PERCENTAGE } \\
\hline $20-30$ years & 14 & $13 \%$ \\
\hline $31-40$ years & 33 & $31 \%$ \\
\hline $41-50$ years & 31 & $30 \%$ \\
\hline $51-60$ years & 25 & $24 \%$ \\
\hline$>60$ years & 2 & $2 \%$ \\
\hline TOTAL & $\mathbf{1 0 5}$ & $\mathbf{1 0 0 \%}$ \\
\hline
\end{tabular}

\subsubsection{Gender}

There were 62 male respondents $(60 \%)$ and 42 female respondents (40\%). Thus, most enterprise owners participating in this study were male as in table 6 .

Table6: The Percentage of Respondents' Gender

\begin{tabular}{|c|c|c|}
\hline Gender & Total & Percentage \\
\hline Male & 62 & $60 \%$ \\
\hline Female & 42 & $40 \%$ \\
\hline TOTAL & $\mathbf{1 0 4}$ & $\mathbf{1 0 0 \%}$ \\
\hline
\end{tabular}

\subsubsection{Enterprise Age}

As shown in table 7, there were 69 enterprises (66\%) running for 5-15 years, 27 (26\%) running for 16-25 years, $6(6 \%)$ running for 26-35 years, $2(2 \%)$ running for 36-45 years, and $1(1 \%)$ running for more than 45 years. In conclusion, most enterprises participating in this study had been running for 5 15 years.

Table7: The Percentage of Enterprise Age

\begin{tabular}{|c|c|c|}
\hline Enterprise Age & Total & Percentage \\
\hline 5 years - 15 years & 69 & $66 \%$ \\
\hline
\end{tabular}




\begin{tabular}{|c|c|c|}
\hline \multicolumn{2}{|c|}{} & $26 \%$ \\
\hline 16 years -25 years & 27 & $6 \%$ \\
\hline 26 years -35 years & 6 & $2 \%$ \\
\hline 36 years -45 years & 2 & $1 \%$ \\
\hline$>45$ years & 1 & $\mathbf{1 0 0 \%}$ \\
\hline TOTAL & $\mathbf{1 0 5}$ & \\
\hline
\end{tabular}

\subsubsection{Monthly Revenue}

Table 8 shows that there were 15 enterprises (14\%) earning below Rp 10,000,000/month, 49 (47\%) earning between Rp10, 000,000-35,000,000/month, 2 (2\%) earning between $\mathrm{Rp} \mathrm{71,000,000-}$ 100,000,000/month, 14 (13\%) earning between Rp 110,000,000-250,000,000/month, 6 (6\%) earning between Rp 260,000,000-500,000,000/month, and 3 (3\%) earning more than Rp. 500,000,000/month. Thus, most enterprises participating in this study earned between $\mathrm{Rp} 10,000,000-35,000,000 / \mathrm{month}$.

\subsection{Descriptive Statistics}

Descriptive Statistics is a form of data analysis describing or depicting collected data (Komala, Suhadak, and NP, 2014). According to Suntono and Kartika (2015), descriptive statistics are used to provide an overview of the data based on the minimum value, maximum value, average, and standard deviation in table 9 .

Table8: The Percentage of Monthly Revenue

\begin{tabular}{|c|c|c|}
\hline Monthly Revenue & Total & Percentage \\
\hline$<\mathrm{Rp} 10.000 .000$ & 15 & $14 \%$ \\
\hline $\mathrm{Rp} 10.000 .000$ - Rp 35.000 .000 & 49 & $47 \%$ \\
\hline $\mathrm{Rp} 36.000 .000$ - Rp 70.000.000 & 16 & $15 \%$ \\
\hline Rp 71.000.000 - Rp 100.000.000 & 2 & $2 \%$ \\
\hline $\mathrm{Rp} 110.000 .000-\mathrm{Rp} 250.000 .000$ & 14 & $13 \%$ \\
\hline Rp 260.000.000 - Rp 500.000.000 & 6 & $6 \%$ \\
\hline$>\operatorname{Rp} 500.000 .000$ & 3 & $3 \%$ \\
\hline TOTAL & 105 & $100 \%$ \\
\hline
\end{tabular}

Table9: Descriptive Data

\begin{tabular}{|l|l|l|l|l|l|}
\hline & \multicolumn{1}{|c|}{ N } & \multicolumn{1}{|c|}{ Min } & Max & \multicolumn{1}{|c|}{ Mean } & \multicolumn{1}{c|}{ Std.Dev } \\
\hline Behavior Control (X1) & 105 & 1 & 4 & 3,007 & 0,35 \\
\hline Subjective Norm (X2) & 105 & 1 & 4 & 3,003 & 0,36 \\
\hline Appreciation strategy (X3) & 105 & 2 & 4 & 3,055 & 0,38 \\
\hline Tax awareness (X4) & 105 & 2 & 4 & 3.097 & 0,38 \\
\hline Tax Compliance (Y) & 105 & 1 & 4 & 3,017 & 0,31 \\
\hline
\end{tabular}

Table 9 shows that behavior control (X1), subjective norm (X2) and tax compliance had the minimum value of 1 while tax awareness and appreciation strategy 2 . All variables had a maximum value of 4 , which means that all respondents gave the highest rating. The average value or mean of all variables is above 3 with the standard deviation below 0.5 . These results indicate that the data dispersion was not too wide.

\subsection{Discussion}

\subsubsection{The Influence of Appreciation strategy tax Awareness}

Appreciation strategy had a positive and significant influence on tax awareness, with t-statistic value of 12.106172 that was significant at $1 \%$ and the coefficient value of 0.737085 . This finding is in line with the Social Learning Theory, confirming that an individual can learn through direct observation and experience (Bandura, 1997 in Jatmiko, 2006). Taxpayers will be more aware and compliant if there is appreciation from the government. With appreciation, taxpayers can interact directly with the government.

This finding also confirms Bornman and Stack (2015), emphasizing that appreciation strategy influenced tax awareness. According to Anwar and Dunija (2016), appreciation motivates an individual someone to be more enthusiastic about an activity. Besides, Dianingtyas (2014) suggested that appreciation is given in the form of material or speech for a particular achievement of an individual or an institution. In conclusion, appreciation for compliant corporate taxpayers can increase the spirit of obeying tax regulations. 


\subsubsection{The Influence of Behavior Control}

Behavior control had a positive influence on tax awareness with the coefficient of 2,370572 and the tstatistic value of 2.7370572 that was significant at $1 \%$. This finding is in line with the Theory of planned behavior in the way that behavioral intention is the main factor for an individual to perform a certain behavior (Winarsih, 2015).

This finding is consistent with Winarsih (2015), confirming that behavioral control influences tax awareness. This means that higher taxpayer behavior control can increase tax awareness. According to Ajzen (1991) in Winarsih (2015), perceived behavior control influences intention based on the assumption that such control has a motivational implication. This means that giving positive motivation regarding taxation results in a firm intention to be more aware of the tax. In addition, Winarsih (2015) suggested that taxpayers perceive that behavior control prevents them from noncompliance behaviors, so motivation is needed to make them realize the importance of tax compliance. However, the finding is contrary to Syahputri (2015) who reported that behavior control did not affect tax awareness.

Table10: Path Coefficient between Constructs

\begin{tabular}{|c|c|}
\hline Relation Between Variables & $\begin{array}{l}\text { Coefficient } \\
\text { (t-statistic) }\end{array}$ \\
\hline Tax awareness -> Tax Compliance & $\begin{array}{l}0,737085 \\
(12,106172) *\end{array}$ \\
\hline Behavior Control -> Tax awareness & $\begin{array}{l}0,236649 \\
(2,370572) *\end{array}$ \\
\hline Subjective Norm -> Tax compliance & $\begin{array}{l}0,313480 \\
(2,593926) *\end{array}$ \\
\hline Appreciation strategy -> Tax awareness & $\begin{array}{l}0,349671 \\
(4,374370) *\end{array}$ \\
\hline Dependent Variable & R Square \\
\hline Tax Compliance & 0.543294 \\
\hline Tax awareness & 0.647007 \\
\hline * Significant at $1 \%$ & \\
\hline
\end{tabular}

\subsubsection{The Influence of Subjective Norm}

With the coefficient of 0.313480 and the t-statistic value of 2.593926 significant at $1 \%$, subjective norm had a positive and significant influence on tax awareness. This finding confirms the Theory of planned behavior in the way that taxpayers' belief in the influence of surrounding people raises their tax awareness.

The finding is consistent with Syahputri (2015) and Hauptman et al. (2015), emphasizing the influence of subjective norm on tax awareness. According to Ajzen (1991) in Winarsih's (2015) subjective norm is an individual perception of social influence in shaping a certain behavior; a taxpayer tends to be more aware of something from the influence of surrounding people, such as family, business partners, even competitors.

In addition, Syahputri (2015) suggested that subjective norm is the extent to which an individual is motivated to follow people's views toward a certain behavior. Subjective norms can be generated through a consideration of opinions from others that eventually influence conscious intention to obey tax rules. Thus, to promote tax awareness, it is necessary for people around a corporate taxpayer to provide positive influences regarding tax. However, the finding is not in line with Winarsih (2015) who reported that subjective norm did not affect tax awareness.

\subsubsection{The Influence of Tax awareness on Tax Compliance}

Table 10 shows that tax awareness had a positive and significant influence on tax compliance with the coefficient value of 0.737085 and the t-statistic value of 12.106172 significant at $1 \%$. This result is following the Theory of Social Learning in the way that an individual can learn through direct observation and experience (Bandura, 1997 in Jatmiko, 2006). By understanding the usefulness of the tax for the development through direct observation, taxpayers will be more obedient in paying taxes. Therefore, the higher the tax awareness, the better the understanding of tax obligations can increase compliance (Astana and Merkusiwati, 2017).

This finding is in line with Astana and Merkusiwati (2017), confirming the influence of tax awareness on tax compliance. According to Astana and Merkusiwati (2017) tax awareness is one of the factors 
that influence the level of tax compliance. Tax awareness is related to taxpayers' sincerity and desire to fulfill their tax obligations (Astana and Merkusiwati, 2017). Taxpayers in Indonesia are given the responsibility to calculate and report their indebted tax so awareness is highly required. Corporate taxpayers are considered aware of the tax regulations when they can understand and implement tax provisions voluntarily without any coercion from other parties.

\subsection{Additional Result}

Table10 shows that the value of R-Square with variable compliance with tax compliance is 0.543294 and R-Square for variable awareness of taxpayer is 0.647007 . These results are categorized as reliable. This data explains that the tax compliance construct can be explained $54.3294 \%$ through the tax awareness construct and the remaining $45.6706 \%$ through other variables outside the model. While the construct of awareness of taxpayers can be explained 64,7007\% through constructs of behavior control, subjective norm, and appreciation strategy, the remaining 35,2993\% are explained through other variables outside the model.

\section{CONCLUSION}

This study was conducted because of the results that have not been consistent with previous studies. This might be caused by the different research models that are used. Previous studies also assumed that all independent variables directly affected tax compliance. This study assumes that the determinant does not directly affect tax compliance but through awareness first. The results of the study support these indirect relationships. Behavior control variables, subjective norm, and appreciation strategy significantly encourage awareness of SMES behavior to obey taxation provisions. More importantly, the appreciation strategy suggested by Hauptman et al. (2015) also increases the awareness of taxpayer.

Two possible implications of research occur from the results of this study. First, this study contributes to the forming of other variables that need to be considered to increase tax awareness: appreciation strategy. Winarsih (2015) states that behavior control influences tax awareness. Syahputri's research (2015) and Hauptman et al. (2015) state that subjective norm affects tax awareness. Knowledge of appreciation strategy also affects tax awareness. These results provide empirical evidence on the suggestions of Bornman and Stack (2015) and Hauptman et al. (2015).

Secondly, for the Directorate General of Taxes or the Tax Service Office (KPP), this study can provide input as well as an overview of the factors that must be improved and considered to increase tax awareness: behavior control, subjective norm, and appreciation strategy. KPP needs to consider the influence of behavior control to increase tax awareness and compliance by giving a positive influence on tax provisions so that it will tend to create motivation from within the corporate taxpayer to be aware and obedient to taxes. In addition, KPP can also consider subjective norms by providing information on tax provisions among SMEs, SMEs colleagues, and families. This is a possibly useful way to influence corporate taxpayer to be aware and obey to taxes through the surrounding environment. The appreciation strategy factor also deserves to be enforced by KPP because the appreciation of taxpayers who obey the tax will increase the desire of the corporate taxpayer to continue to obey the tax provisions.

This study cannot be separated from limitations. This study only uses three independent variables, which are behavior control, subjective norms, and appreciation strategy. Further research should append independent variables about the factors that influence awareness and tax compliance such as trust in the government and the use of tax funds.

\section{ACKNOWLEDGEMENT}

This research is fully funded by The Ministry of Research, Technology and Higher Education (Kemenristekdikti), The Republic of Indonesia under the Basic Research Grant scheme for 2019/2020.

\section{REFERENCES}

[1] Anwar, \& Dunija, T. (2016). Pengaruh sistem Reward dan Punishment terhadap peningkatan disiplin kerja karyawan PT.Tunggal Perkasa Plantation-3 kecamatan Sampoiniet kabupaten Aceh Jaya. Jurnal Serambi Akademica, IV (1), 28-36.

[2] Astana, I. W. S., \& Merkusiwati, N. K. L. A. (2017). Pengaruh Penerapan Sistem Administrasi Perpajakan Modern Dan Kesadaran Wajib Pajak Pada Kepatuhan Wajib Pajak. Jurnal Akuntansi Universitas Udayana Januari, 181, 2302-8556. 
[3] Bornman, M., \& Stack, E. M. L. (2015). Specific rewards for tax compliance : Responses of small business owners in. E-Journal of Tax Research, 13(3), 799-818.

[4] Dianingtyas, A. (2014). Pengaruh Penghargaan dan Kebutuhan Aktualisasi Diri Terhadap Prestasi Kerja Karyawan Pada PT. Telkom Kotabaru Yogyakarta. Universitas Negeri Yogyakarta.

[5] Engida, T. G., \& Baisa, G. A. (2014). Factors Influencing taxpayer's complince with the tax system: An empiricial study in Mekelle City, Ethiopia. E-Journal of Tax Research, 12(2), 433-453.

[6] Ghozali, I., \& Latan, H. (2014). Partial Least Squares SmartPLS 3.0 (2nd ed.). Semarang: Badan Penerbit Universitas Diponegoro Semarang.

[7] Hariyanto, B. (2012). Pengertian Kepatuhan Wajib Pajak Menurut Ahli. Retrieved January 3, 2017, from http://www.bambanghariyanto.com/2012/06/pengertian-kepatuhan-wajib-pajak.html

[8] Hauptman, L., Gurarda, S., \& Korez-Vide, R. (2015). A taxonomy of the tax compliance literature: Further findings, problems and prospects. Australian Tax Forum, 16(3), 137-320. https://doi.org/10.4335/13.3. 639-659(2015)ISSN

[9] Indriyani, P. A., \& Sukartha, I. M. (2014). Tanggungjawab Moral, Kesadaran Wajib Pajak, Sanksi Perpajakan, dan Kualitas Pelayanan Pada Kepatuhan Pelaoran Wajib Pajak Badan. E-Jurnal Akuntansi Universitas Udayana, 2, 431-443.

[10] Jatmiko, A. N. (2006). Pengaruh Sikap Wajib Pajak Pada Pelaksanaan Sanksi Denda, Pelayanan Fiskus dan Kesadaran Perpajakan Terhadap Kepatuhan Wajib Pajak ( Studi Empiris Terhadap Wajib Pajak Orang Pribadi di Kota Semarang ). Tesis, 86.

[11] Khairah, U. (2015). Pengaruh Manfaat yang Dirasakan Wajib Pajak, Kepercayaan Terhadap Aparat Pajak, Sosialisasi Pajak, dan Penghasilan Wajib Pajak Terhadap Kepemilikan Nomor Pokok Wajib Pajak (NPWP) (Studi Empiris Pada Pengusaha UMKM di Kota Pekanbaru). Jurnal Online Mahasiswa Universitas Riau, 1-16.

[12] Komala, K. C., Suhadak, \& NP, M. G. W. E. (2014). Pengaruh Kualitas Pelayanan Perpajakan Terhadap Kepatuhan Wajib Pajak Badan (Studi Pada Kantor Pelayanan Pajak Madya Malang). Student Journal, 1-9.

[13] Lesnik, T., Kracun, D., \& Jagric, T. (2014). Tax Compliance and Corporate Income Tax - The Case of Slovenia. Journal of Local Self-Government, 12(4), 793-811. https://doi.org/10.4335/12.4.793-811 (2014) ISSN

[14] Novriansyah, M. (2016). Pengaruh Kepatuhan, Pemahaman, Manfaat yang Dirasakan, SAnksi Denda dan Pelayanan Fiskus Terhadap Kesadaran Wajib Pajak dalam Pelaporan Kewajiban Perpajakan pada Restoran di Tanjungpinang. Jurnal Umrah.

[15] Sapiei, N. S., Kasipillai, J., \& Eze, U. C. (2014). Determinants of tax compliance behaviour of corporate taxpayers in Malaysia. eJournal of Tax Research, 12(2), 383-409.

[16] Serim, N., Inam, B., \& Murat, D. (2014). Factors Affecting Tax Compliance of Taxpayers: The Role of Tax Officer The Case of Istanbul and Canakkale *. Business and Economics Research Journal, 5(2), $19-31$.

[17] Suntono, \& Kartika, A. (2015). Pengaruh Pemahaman Peraturan Pajak dan Pelayanan Aparat Pajak Terhadap Kepatuhan Wajib Pajak Dengan Preferensi Risiko Sebagai Variabel Moderasi (Studi Kasus Pada UMKM yang Terdaftar Di KPP Pratama Demak). Dinamika Akuntansi, Keuangan Dan Perbankan, 4(1), 29-38. https://doi.org/10.1017/CBO9781107415324.004

[18] Syahputri, Y. F. (2015). Analisis Faktor-faktor yang Mempengaruhi Ketidakpatuhan Wajib Pajak (Studi Empiris Pada Pengusaha UMKM Di KPP Pratama Pekanbaru Senapelan). Jurnal Online Mahasiswa Universitas Riau, 2(2), 1-15.

[19] Winarsih, E. S. (2015). Faktor-Faktor yang Mempengaruhi Niat Ketidakpatuhan dalam Membayar Pajak (Studi Empiris Terhadap Wajib Pajak PBB-P2 Kabupaten Sukoharjo). Magistra, (91), 8-20.

Citation: Hadri Kusuma, Famita Azzakhusna. " Tax Awareness and Compliance: An Empirical Study on Small and Medium-Sized Enterprises (SMES)" International Journal of Managerial Studies and Research (IJMSR), vol 7, no. 10, 2019, pp. 8-17. doi: http://dx.doi.org/10.20431/2349-0349.0710002.

Copyright: (C) 2019 Authors. This is an open-access article distributed under the terms of the Creative Commons Attribution License, which permits unrestricted use, distribution, and reproduction in any medium, provided the original author and source are credited. 